\title{
Fedme er ikke bare et kaloriproblem
}

\section{Nye forskningsfunn støtter mis- tanken om at både tarmflora og arv påvirker hvor fete vi blir.}

I en nylig publisert studie ble mus behandlet med gastrisk bypass (1). Musene tapte raskt vekt, og forskerne mener vekttapet ikke bare skyldtes nedsatt kaloriinntak, men også

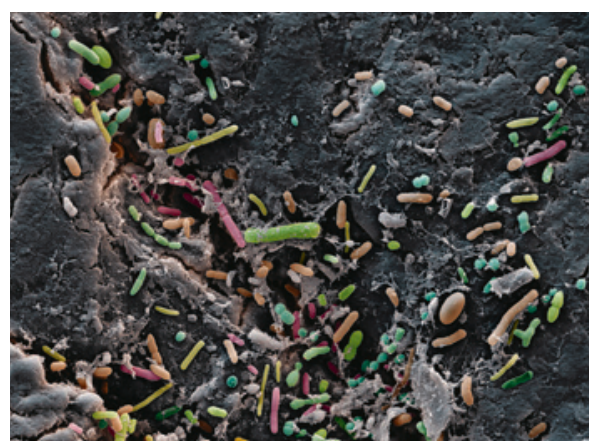

Illustrasjonsfoto Science Photo Library/NTB scanpix postoperative endringer i musenes tarmflora. Overføring av tarmbakteriene fra opererte mus til mikrobefrie mus slanket nemlig mottakerne.

I en annen studie ble mus fra over hundre ulike, innavlede musestammer fôret med mye fett og sukker (2). Den energirike dietten ga stammespesifikke vektforskjeller som ikke kan forklares av matinntaket, men som kan tyde på en genetisk bestemt forutsetning for mengden fettvev (set point). Genomanalysen avslørte 11 DNA-områder assosiert med fedmetilbøyelighet - flere av dem er også påvist hos mennesker. Det var også en sterk assosiasjon mellom genotype og endringer av tarmfloraen.

- Tarmbakterienes betydning for overvekt og vektendring er sannsynligvis undervurdert, og dette spennende forskningsfeltet er bare i sin spede begynnelse, sier Jøran Hjelmesæth, professor ved Avdeling for endokrinologi, sykelig overvekt og forebyggende medisin, Universitetet i Oslo og leder av Senter for sykelig overvekt ved Sykehuset i Vestfold.

- Om noe, og eventuelt hvor mye, av vektreduksjonen etter gastrisk bypass hos mennesker som kan forklares av endring i tarmfloraen, er imidlertid høyst uavklart. Hypotesene om et genetisk bestemt «set point» for mengde fettvev og sammenheng mellom genotype og endring av tarmflora, er veldig spennende. Denne studien belyser på en elegant måte hvor viktig interaksjoner mellom gener og miljøfaktorer er.

\section{Haakon B. Benestad}

h.b.benestad@medisin.uio.no

Universitetet i Oslo

\section{Litteratur}

1. Liou AP. Paziuk M, Luevano JM Jr et al. Conserved shifts in the gut microbiota due to gastric bypass reduce host weight and adiposity. Sci Transl Med 2013; 5: 78ra41

2. Parks BW, Nam E, Org E et al. Genetic control of obesity and gut microbiota composition in response to high-fat, high-sucrose diet in mice. Cell Metab 2013; 17: 141-52.

\section{LSD gir ikke psykiske problemer}

\author{
Brukere av psykedelika har ikke dårligere psykisk helse enn andre.
}

Forskere fra Norges teknisk-naturvitenskapelige universitet har analysert data fra en amerikansk befolkningsstudie der et representativt utvalg av den voksne befolkningen ble bedt om å svare på spørsmål rundt eget rusforbruk og psykisk helse (1). Blant de om lag 130000 som svarte, hadde nesten 22000 , dvs. over $13 \%$, prøvd LSD, psilocybin, meskalin eller peyote i løpet av livet. Blant disse var det en overvekt av unge, ugifte menn av hvit eller blandet herkomst med høyere utdanning og god økonomi.

Det var ingen sammenheng mellom bruk av psykedelika og opplevd alvorlig psykisk stress, mottatt eller følt behov for psykisk helsehjelp og symptomer på psykiatrisk sykdom i løpet av det siste året. Enkelte brukere av psykedelika hadde signifikant bedre mental helse enn andre, og bruk av LSD det siste året var assosiert med færre tilfeller av opplevd uttalt psykisk stress.

- Denne typen befolkningsstudier må tolkes med forsiktighet, sier Jørgen Bramness, professor ved Senter for rus- og avhengighetsforskning, Universitetet i Oslo. - Blant annet kan man ikke bruke disse resultatene til å si noe om årsaksforhold. Det er ikke tilfeldig hvem som prøver psykedelika, og kanskje er det slik at nettopp disse personene har en bedre mental helse i utgangspunktet. Studien viser riktignok, i likhet med tidligere studier, at vi nok overdriver faren ved bruk av psykedelika generelt, og LSD spesielt, i alle fall hvis vi skal dømme ut ifra narkotikalovgivningen. Det er likevel et langt skritt herfra til å si at psykedelika er sunt og noe vi bør ta for å få et lykkeligere liv. Det har vi foreløpig ingen holdepunkter for, konkluderer Bramness.

\section{Kari Tveito}

kari.tveito@me.com

Oslo

\section{Litteratur}

1. Krebs TS, Johansen P- $\emptyset$. Psychedelics and mental health: a population study. PLoS ONE 2013; 8: e63972

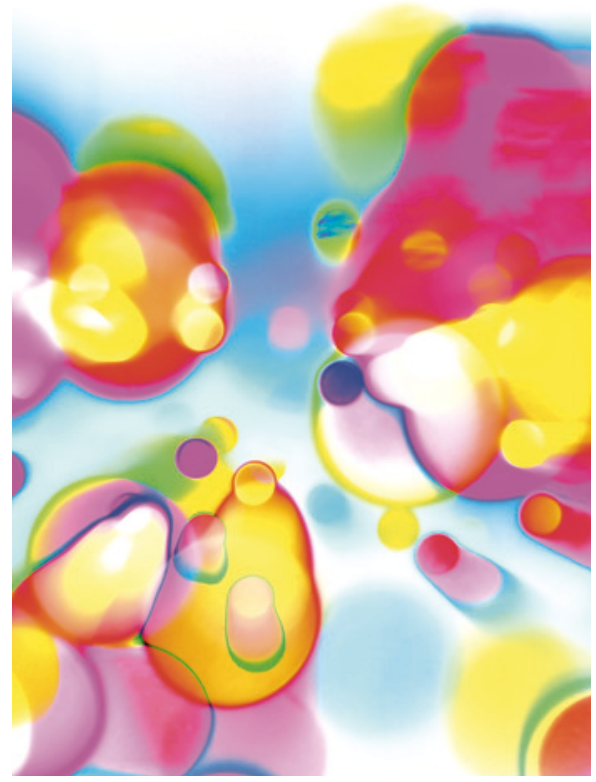

Illustrasjonsfoto Thinkstock 